\title{
Euroson Schools
}

EFSUMB oppfordrer ultralydmiljøer i de ulike medlemsland til å organisere kurs. Disse er ofte målrettet mot et bestemt organsystem, og holder høy internasjonal standard. Denne kursvirksomheten er en viktig del av EFSUMBs tiltak for kontinuerlig oppdatering av ultralydferdighetene til medlemmene og er svært aktuelle for norske deltakere. En oversikt over kommende kurs og en rekke foredrag fra gjennomførte kurs finnes på EFSUMBs hjemmeside: www.efsumb.org/intro/home. asp 